\title{
Comments
}

\section{CHOICE OF A CORPORATE DOMICILE}

\section{I}

\section{INTRODUCTION}

For the better part of a century, the practice of incorporating business enterprises under the laws of certain "liberal" states has been widespread. ${ }^{1}$ These states have traditionally offered three inducements to those seeking a favorable corporate climate: a low initial cost of incorporation coupled with a low tax rate thereafter, a simple incorporation procedure, and a broad enabling act. ${ }^{2}$ These inducements were particularly attractive during the early part of the century. At that time many states imposed severe limitations upon the actions of business enterprises inconporated under their laws, ${ }^{3}$ a disadvantage which normally could be avoided by incorporation under the laws of a "liberal" state." The taxation schemes of other states discriminated against domestic corporations in favor of foreign ones. ${ }^{b}$

During the 1920's, however, a movement arose to re-draft outmoded state corporation statutes. ${ }^{6}$ In 1929 , for example, California adopted a General Corporation $\mathrm{Law}^{7}$ designed to put California on a competitive basis with Delaware, Nevada, and other incorporating states in offering legitimate corporate advantages and facilities. ${ }^{8}$ Because of its expanded enabling act, and because its taxation scheme in most cases has not encouraged out-of-state incorporation, many of the traditional reasons for seeking a foreign corporate domicile do not apply to California. However, other provisions of the California General Corporation Law, operatimg in conjunction with the California Corporate Securities Law ${ }^{0}$ passed in 1917 and the administrative regulations promulgated thereunder, ${ }^{10}$ were designed

1 See Larcom, The Delatware Corporation 1-17, 155-79 (1937); Jennings, The Role of the States in Corporate Regulation and Investor Protection, 23 LAw \& CoNTEMP. Pros. 193, 194-98 (1958).

2 See LARCOM, op. cit. supra note 1, at 15-26.

3 For example, early laws often limited the authorized capital of the business corporation, the purposes for which it could be formed, and the length of its life. They often failed to provide for the power to issue more than one class of stock, to hold their own stock or the stock of other corporations, or to merge or consolidate. In addition, sbares were often assessable without limit, and double liability to the corporation's creditors was often imposed upon the shareholders. See Brandeis, dissenting, in Louis K. Liggett Co. v. Lee, 288 U.S. 517, 550-56 (1933); Ballantine, Plans for a Modernized Incorporation Law, 16 CALIF. L. REv. 425 (1928); Dodd, Statutory Developments in Business Corporation Law, 1886-1936, 50 HARv. L. Rev. 27, 31-52 (1936).

4 See note 49 infra.

5 For example, the state of incorporation may impose a lheavy tax on capital stock or intangibles of domiciliary corporations, which is not paid by foreign corporations doing business in the state. See 1 Hornstem, Corporation Law arid Practice $\$ 77$ (1959) [hereinafter referred to as HoRnSTEIN] ; Garrett, Where to Incorporate, 37 IrI. B.J. SUPPLEMENT 386 (1949).

6 See Baltantine, Corporations $\$ 11$ (rev. ed. 1946); Jennings, The Role of the States in Corporate Regulation and Investor Protection, 23 LAW \& ConTEMP. ProB. 193, 196-98 (1958).

7 Cax. Corp. Code $\$ \S 100-6804$.

8 Ballantine, Changes in the California Corporation Laws (1929), 17 CaLIF. L. REv. 529 (1929); Ballantine, Questions of Policy in Drafting a Modern Corporation Law, 19 CaLIF. $\mathrm{L}$. REv. 465 (1931).

- Cax. Corp. Cone $\$ \S 25000-26104$.

10 Tit. 10 Car. Adas. CoDe $\$ \$ 300-860$. 
to protect creditors, security holders, and prospective purchasers of securities, rather than to facilitate corporate operations. In most cases, however, these limitations of management prerogatives do not constitute sufficient reasons to avoid a California domicile.

The comment will compare the General Corporation and Corporate Securities Laws of California, one of the leading states in the protection of security holder and public interests, with the laws of two of the traditionally management-oriented states, Delaware and Nevada. ${ }^{11}$ It will examine some of the advantages and disadvantages to be weighed by a California attorney in deciding whether to incorporate a busmess in Cahifornia or to seek a foreign domicile. Unless the contrary is indicated, the comment will be limited to companies that will be selling some of their securities or doing some business in California. ${ }^{12}$ Necessarily it will emphasize the factors of interest to promoters, corporate managers, or controlling shareholders, since it is these groups that determine the corporate situs.

\section{II}

\section{TAXES AND OTHER COSTS}

Savings in state taxes and fees, as well as in the cost of compliance with state and federal regulatory statutes, may influence the choice of a corporate domicile. Small companies doing business in a single state will normally find that costs would be minimized by incorporation in the state where business is done. The problem most often faced by such small companies is to determine whether out-of-state incorporation would be prohibitively expensive, assuming that it would be desirable for other reasons. Companies that are larger or that are doing business in several states may mimimize their costs through the choice of a state of incorporation. Since in most cases cost differentials among the states are not large, they do not constitute a major factor in the choice of a corporate domicile. However, care should be taken to avoid incorporation in those few states that discrininate through the imposition of siguificantly higher costs on domiciliary corporations than on similarly situated foreign corporations. ${ }^{13}$

\section{A. Initial Costs}

An infant corporation must pay an orgamization fee to the state of incorporation when it files its articles of imcorporation. ${ }^{14}$ Some states impose a flat fee; ${ }^{15}$ others impose a fee which is based on the authorized capital stock ${ }^{16}$ or the consider-

11 For other treatments of California corporation laws, see Jennings, The Role of the States in Corporate Regulation and Investor Protection, 23 LAw \& CoNTEMP. ProB. 193 (1958); Wheat, Issuance of Securities Under the California Corporate Securities Law, Continuing Education of Bar, Advistivg CALIFORNIA BusINEss ENTERPRISES 497 (1958); Dahlquist, Regulation and Civil Liability Under the California Corporate Securities Act: I-IV, 33 CAIIF. L. REv. 343 (1945), 34 CaxIr. L. REv. 344, 543, 695 (1946) ; Dalton, The California Corporate Securities Act, 18 CALTF. L. Rev. 115, 255, 373 (1930).

12 For a brief consideration of enterprises that sell no securities and do no business in California, see the text at notes 120-22 infra.

13 For example, for a corporation with $\$ 10,000,000$ capitalization, Iowa would impose an organization fee of $\$ 20$. IowA Acrs, 58 G.A. ch. 321, $\$ 124$ (1959). Illinois would impose a fee of $\$ 5,020$. Irt. ANn. Stat. ch. 32, $\$ 157.129$ (Smith-Hurd 1954). Alabama would impose a fee of $\$ 10,000$. Ara. CoDe tit. 10, $\$ 21$ (8) (1959 Supp.).

14 See 1 HORNSTEIN $\$ 82$.

15 See, e.g., Iowa AcTs, 58 G.A. ch. 321, $\$ 124$ (1959), which imposes a flat fee of $\$ 20$.

16 See, e.g., Dex. Cone ANN. tit. 8, §361 (1953). 
ation received for the shares, ${ }^{17}$ and which increases ${ }^{2}$ ither at a fixed ${ }^{18}$ or at a declining rate. ${ }^{19}$ California, Delaware, and Nevada all employ a declining rate fee based on the authorized capital stock, ${ }^{20}$ Delaware having the lowest rates of the three and Nevada the highest. Though the fees imposed by the three states are considerably higher than those of the lowest-cost states, they do not seem high enough to constitute a significant deterrent ${ }^{21}$ should these states prove desirable for other reasons.

Normally, a corporation must also pay an entrance fee in each state in which it is to do business, other than the state in which it is incorporated..$^{22}$ In most states it is a fiat fee. ${ }^{23}$ In some, however, it is an increasing fee equal to ${ }^{24}$ or somewhat higher than ${ }^{25}$ the organization fee imposed by the state. If a higher rate is used, however, the tax is apportioned according to the contacts the corporation lias with the state. ${ }^{28}$

There is usually little incentive to incorporate a multi-state business within a state in order to avoid its entrance fee, since it is rare for a state to impose an entrance fee that is significantly higher than its organization fee. ${ }^{27}$ Entrance fees may be more significant for companies operating within one state, however, since such companies can avoid entrance fees entirely by incorporating where they do business. For example, the size of the $\$ 350$ California fee ${ }^{28}$ may discourage a smaller corporation from seeking a foreign domicile. Since it is a fiat fee, lowever, it is a less important consideration for larger business enterprises.

A corporation may face additional costs in states in which it sells its securities. ${ }^{29}$ If it plans to sell securities of its own issue in Cahfornia, it must first obtain a permit from the Commissioner of Corporations. ${ }^{30} \mathrm{It}$ must pay a permit fee, computed on the value of the securities to be issued, which increases at a declining rate. ${ }^{31}$ It must also obtain at its own expense the financial reports and the other information required by the Commissioner. ${ }^{32}$ Delaware and Nevada impose no such fees upon the sale of securities, since neither state has a "blue sky" law. ${ }^{38}$

17 See, e.g., Ir工. ANN. STAT. ch. 32, §157.129 (Smith-Hurd 1954).

18 Ibid.

19 Some states actually employ a declining percentage rate. See, e.g., DEL. CoDE ANN. tit. 8 , $\$ 361$ (1953). Others achieve the same result by employing a fixed amount that is graduated upward as the capitalization imcreases. See, e.g., CAL. Gov'T Code $\$ 12201$; NEv. REv. StaT. $\$ 78.760$ (1957). (1957).

20 CaL. Gov't Code $§ 12201$; Det. Code AnN. tit. 8 , § 361 (1953); Nev. Rev. Stat. $\$ 78.760$

21 Compare the California, Delaware, and Nevada fees, set out in notes 46-48 infra, with the Illinois and Alabama fees mentioned in note 13 stupra.

22 See 1 HoRNSTEIN $\S 85$.

23 See, e.g., CaL. Gov't Code $\$ 12204$ (\$350); DeI. Code ANn. tit. 8, § 341 (\$25) (1953).

24 See, e.g., NEv. REv. STAT. $\$ \$ 78.760$ (1957), 80.050 (1960).

${ }^{25}$ See, e.g., N.Y. TaX Laws $\$ \$ 180,181$.

26 Ibid.

27 But cf. CAL. Gov'r CODE $\$ \S 12201,12204$.

23 CAI. Gov't CODE $\$ \$ 12201,12204$.

${ }^{29}$ For a general discussion of the requirements of blue sky laws in the United States, see Loss \& COWETT, BLUE SKY LAW 17-42 (1958).

${ }^{30}$ CaI. Corr. Code $\$ 25500$.

31 CAL. CORP. CODE $\$ 26003$. A corporation conducting negotiations in California for the sale of securities of its own issue before it obtains an ordinary permit, nust secure a $\$ 25$ negotiating permit. CAI. CORP. CODE $\$ \S 25516-17,26002$.

82 CaI. Corf. Code $\$ 25506$; Tit. 10 CaL. AdM. Code $\$ \S 426,445,446$.

a3 See Loss \& CowetT, Brue Sky LAW at 17 (1958). 
Under the present California Corporate Securities Law, the permit fee paid by a California corporation is based upon the total value of securities to be issued, whether sold in California or elsewhere. ${ }^{34} \mathrm{~A}$ foreign corporation, however, pays a California permit fee only upon securities to be sold in Cahifornia. ${ }^{35}$ Moreover, if a foreign corporation sells securities to California residents in a transaction that is entirely negotiated and completed outside the state, or if it sells securities to foreign underwriters under a "firm commitinent" underwriting agreement, it is deemed to sell no security of its own issue in this state, and therefore it may escape the California permit fee entirely. ${ }^{36}$ Therefore, in some cases it may prove less expensive for a corporation to sell its securities if it is incorporated outside Califorma.

A company that incorporates in a state where it does no business may encounter additional costs that it would not otherwise face. For example, foreign incorporation will result in the loss of the intrastate exemption to the federal securities law, thereby subjecting a company to the additional cost of federal registration unless it can claim another exemption. ${ }^{37}$ Moreover, it may prove necesary to einploy a corporation service company to perform the necessary formalities in the state of incorporation, ${ }^{38}$ particularly if that state is far from the actual place of business. This normally will cost about $\$ 100$.

\section{B. Continuing Costs}

A corporation normally will incur continuing costs in any state from which it derives income. ${ }^{39}$ For example, under the California franchise and corporate income taxes, net income derived from California sources is subject to a $5.5 \%$ tax, whether or not the corporation is qualified to do busmess in Califorma. ${ }^{40}$ In Delaware both domestic and foreign corporations pay a 5\% net income tax on income derived from within the state; ${ }^{41}$ Nevada has no continuing tax based upon net income. Since these taxes apply with equal force to similarly situated domestic and foreign corporations, lowever, they should have no effect upon the choice of a corporate domicile.

Additional continuing costs nay be incurred by a company that incorporates

34 CAI. CORP. CODE $\$ \S 26003,25500,25003$.

35 On their face, the California statutes, cited in note 34 supra, apply to any security issued by any company, whether domestic or foreign. With regard to foreign companies, however, they have been applied in practice only to securities offered or sold within the state. See Dahlquist, Regulation and Civil Liability Under the California Corporate Securities Act: II, 34 CAIIF. L. REv. 344, 380-85 (1946).

36 See the text at notes $95-105$ infra for a discussion of firm commitment underwriting. See also Dahlquist, op. cit. supra note 35.

3748 Stat. 906 (1934), 15 U.S.C. $\$ 77 \mathrm{c}$ (1958).

38 E.g., file and record the charter, bold the organizational meeting, and elect the permanent directors.

${ }^{30}$ See, e.g., 1 HorNstenv at $\S 83$. But see also 73 Stat. 555 (1959), 15 U.S.C. $\$ 381$ (Supp. 1960), which provides that no state net income tax can be imposed upon a corporation engaged in interstate commerce when its only activity within the state is solicitation of orders to be filled out-of-state.

40 The California franchise tax is imposed upon enterprises incorporated in or qualified to do business in California, measured by $5.5 \%$ of the net income derived from sources within the state. CAI. REv. \& TAX. CODE $\$ \$ 23151,25101$. The Cahifornia corporate income tax imposes a $5.5 \%$ tax upon the net income derived from California sources by enterprises not qualified to do business in Cahifornia. CAI. REv. \& TAX. CoDE $\$ \$ 23501,23503$; West Publishing Co. v. McColgan, 27 CaI. 2d 705, 166 P.2d 861 (1946), aff'd, 328 U.S. 823 (1946).

11 DEL. Code ANN. tit. 30, $\$$ 1902-03 (1953). 
in a state froin which it derives no income. For example, Nevada charges an annual fee of $\$ 10,{ }^{42}$ California has a mininum franchise tax of $\$ 100,43$ and Delaware imposes a franchise tax based on authorized capital and computed according to a coniplex formula. ${ }^{44}$ In addition, all three states require a domiciliary corporation to maintain a principal office and resident agent within the state. ${ }^{45} \mathrm{~A}$ company incorporated under the laws of a state in which it does no business may find it necessary to perform this duty through a corporation service company, at a cost of approximately $\$ 50$ to $\$ 100$ a year.

\section{Computation of Expenses}

For a more graphic view of the effect of state taxes and costs, consider two hypothetical corporations with authorized capital of $\$ 100,000$ and $\$ 10,000,000$, respectively. If the two sold all their securities and did all their business in Califorma, the fees for incorporating them in California would be about $\$ 348$ and $\$ 2,898,46$ respectively, plus the cost of obtaining the reports required by the Commissioner of Corporations. Suppose, however, that they incorporated under the laws of one of the "liberal" states, and then qualified to do business in California. As Delaware corporations they would face initial fees of about $\$ 658$ and $\$ 2,848,47$ respectively, while as Nevada corporations they would pay about $\$ 723$

42 NEv. REv. STAT. \$78.150 (1959).

43 CAL. REv. \& TAX. Code $\$ \$ 23151,23221,23153$.

44 Det. Code ANn. tit. $8, \S \S 501,503$ (1953).

45 CaL. CoRp. Code $\S \S 301$ (c), 3301 ; Del. Code AnN. tit. 8, $\S \S 131-36$ (1953) ; Nev. Rev. STAT. $\$ \$ 78.090-110$ (1959).

46 For the purposes of this and the two following footnotes, assume that corporation $A$ has an authorized capital of $\$ 100,000$, and that corporation $B$ has an authorized capital of $\$ 10,000,000$. Assume that both will sell $\$ 100$ par shares (for purposes of computing the Delaware franchise tax); that all the shares will be sold in California; and that all business will be conducted in California. Assume also that both corporations will earn a net income equal to a $10 \%$ return on invested capital.

Initial costs for a California domiciliary corporation.

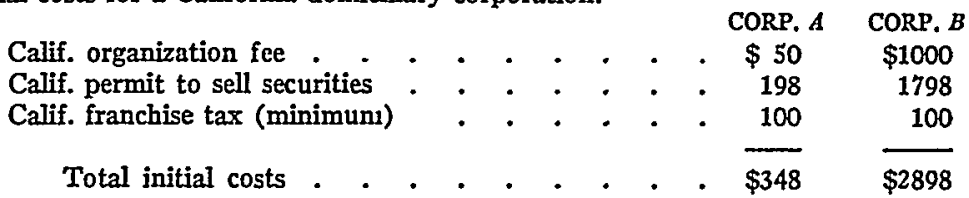

Continuing costs for a California domiciliary corporation.

Calif. franchise $\operatorname{tax}$. . . . . . . . . $\$ 550$

CORP. B

47 Initial costs for a Delaware domiciliary corporation.

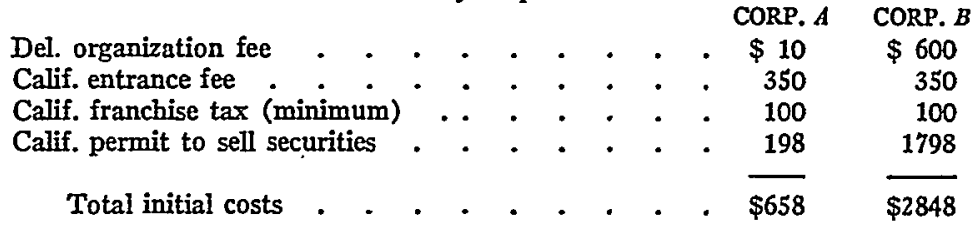

Continuing costs for a Delaware domiciliary corporation.

Del. franchise tax . . . . . . . , . $\$ 11$

Calif. franchise tax..$+ \quad \cdot \quad \cdot \quad \cdot \quad \cdot \quad \cdot \quad \cdot 550$ 
and $\$ 3,748,{ }^{48}$ respectively. They would still have to obtain the reports required by the Commissioner of Corporations. In addition, they might also face the costs of federal securities registration, as well as the expense of using a corporation service company.

As discussed previously, under the present California Corporate Securities Law a foreign corporation may in some circumstances pay a reduced California permit fee, or may avoid the fee entirely. In the latter case, the initial cost of incorporating the two hypothetical enterprises in Delaware would be reduced to about $\$ 460$ and $\$ 1,050$, respectively, while the cost of incorporating them in Nevada would be about $\$ 525$ and $\$ 1,950$, respectively.

Differences between continuing costs imposed on California and on foreign corporations do not appear large enough to be important.

\section{III}

\section{PROVISIONS OF THE GENERAI CORPORATION LAWS}

The general American rule in conflicts of law is that the internal affairs of a corporation are governed by the laws of the state of incorporation..$^{49}$ This rule has often encouraged business enterprises located in states with inadequate enabling acts to incorporate elsewhere, particularly since the corporation service companies stand ready to organize a foreign corporation quickly and at a relatively low cost..$^{50}$ However, the General Corporation Laws of California, Delaware, and Nevada are in most respects adequate as enabling acts. ${ }^{51}$ The differences among the three states stem primarily froin the California provisions designed to protect the interests of

48 Initial costs for a Nevada domiciliary corporation.

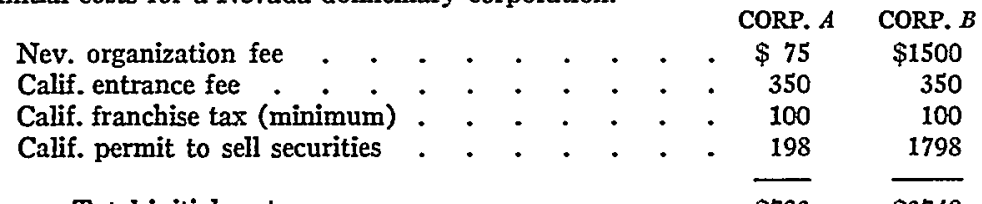

Total initial costs . . . . . . . . . . . $\$ 7723 \quad \$ 3748$

Continuing costs for a Nevada domiciliary corporation.

\begin{tabular}{|c|c|c|c|c|c|c|c|c|c|c|c|}
\hline \multirow{3}{*}{\multicolumn{2}{|c|}{$\begin{array}{l}\text { Nev. annual fee } \\
\text { Calif. franchise tax }\end{array}$}} & & & & & & & & & & CORP. $E$ \\
\hline & & $\cdot$ & • & $\cdot$ & $\cdot$ & ${ }^{\circ}$ & - & $\cdot$ & . & $\$ 10$ & \\
\hline & . . & • & . & . & . & . & . & . & . & 550 & 55,000 \\
\hline & & & 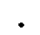 & 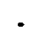 & . & 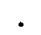 & . & 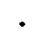 & & $\$ 560$ & ,010 \\
\hline
\end{tabular}

49 See Southern Sierras Power Co. v. Railroad Comm., 205 Cal. 479, 271 Pac. 747 (1928); 17 Fletcher, Cyclopedia Corporations $\$ 8445$ (rev. vol. 1960); 2 Rabed, The Conflict of Laws: A CoMparative StUdy 31-33, 69-93 (2d ed. 1960).

The California courts occasionally assume jurisdiction to consider the internal affairs of a foreign corporation, particularly if it does business solely in California. Sharp v. Big Jim Mimes, 39 Cal. App. 2d 435, 103 P.2d 430 (1940); 3 Wrrkin, Sumdmary of California Law 2407 (1960 ed.). Generally, however, they appear to apply the law of the state of domicile rather than the law of California. See Signal Oil \& Gas Co. v. Ashland Oil \& Ref. Co., 49 Cal. 2d 764, 322 P.2d 1 (1958); Sharp v. Big Jim Mines, supra. California may apply its own law to business done within the state, however, such as the sale of securities, Gillis v. Pan Am. W. Petroleum Co., 3 Cal. 2d 249, 44 P.2d 311 (1935), or the execution of contracts, e.g., CaL. CoRP. CODE $\S 803$.

50 See Larcom, The Delaware Corporation 10-17 (1937).

51 See the criteria set forth in 1 HoRnstein $\$ 86$; RohrLich, Organizing Corporate and OTHER BUSINESS ENTERPRISES $\$ 6.01$ (rev. ed. 1953). 
the security holders and of the general public. The situations in which these differences may prove significant will be examined at this point. A more complete comparison of the three General Corporation Laws may be found in the Appendix infra.

\section{A. Cumulative Voting}

In an effort to increase the common shareholders' power over and representation on the board of directors, the California Corporations Code makes cumulative voting a mandatory provision for all domestic corporations. ${ }^{62}$ In Delaware and Nevada, cumulative voting is permissive only ${ }^{63}$ In addition, the California code, in order to insure that cumulative voting will not be circumvented, forbids directors' terms of office to be staggered, ${ }^{54}$ a practice allowed in both Delaware and Nevada. ${ }^{55}$ It also forbids the reduction of the size of the board below five witlout the consent of more than eighty per-cent of the voting shares-the number that could elect an entire board of five under cumulative voting. ${ }^{58}$

Among the objections raised by critics of cumulative voting, several may ocasionally prove significant. One objection is the possibility that a rival company might be able to plant a spy on the board of directors im order to obtain commercial secrets. A second is that the presence on the board of a crank or the representative of a dissident faction might impede its smooth functioning, or miglit tend to make the management overly conservative and unwilling to take necessary risks. CuInulative voting may also increase the likelihood of a proxy fight, wlich may be both expensive and disruptive to the corporation. Finally, under cumulative voting an individual shareholder miglit find it somewhat easier to induce corporate action favorable to his interests alone. A 1951 study indicated that in practice the first of these possibilities happens rarely, if at all, while the others occur only infrequently. ${ }^{57}$ Nevertheless, whether these objections are justified or not, cumulative voting is strongly opposed in some management circles. ${ }^{58}$

Before foreign mcorporation is employed as a device to avoid California's cumulative voting requirement, however, several other factors slould be considered. One is the possibility that, under the present California Corporate Securities Law, the absence of cumulative voting might make it difficult for a corporation to obtain a permit to sell securities in California, particularly if its principal place of business is in this state. ${ }^{58}$ Secondly, although the question has never arisen in California, a corporation could probably enjoin the seating of a spy on its board of directors. ${ }^{.00}$

52 CaL. CoRp. CoDe $\$ 2235$.

E3 Dex. Code Ann. tit. 8, $\$ 214$ (1953); Nev. Rev. StAT. $\$ 78.360$ (1957).

64 CaI. Corp. Code $\$ 805$.

65 Dex. Code ANN. tit. 8, §141 (1953); Nev. Rev. Stat. $\$ 78.330$ (1957).

56 CAL. CORP. CODE $\$ 501$.

57 See Winliams, Cumulative Voting for Directors 68, 127, 129, 161, 163, 165 (1951).

68 Id. at 182; Steadman \& Gibson, Slzould Cumulative Voting for Directors be Mandatory? - A Debate, 11 Bus. LAw. 22-30 (1955); Sturdy, Mandatory Cumulative Voting: An Anachronism, 16 Bus. LAw. 550-76 (1961).

59 The California Commissioner of Corporations will "view with disfavor" the sale of shares without cumulative voting rights by a foreign corporation with its principal place of business or principal busimess in California. For other foreign corporations, it will be a negative factor in determining whether the sale is "fair, just, and equitable." Tit. 10 CAr. ADM. CODE $\$ 367.1$.

$60 \mathrm{CAL}$. CORP. CODE $\$ 811$ permits the superior court, upon petition by the holders of $10 \%$ of the shares, to remove a director for fraudulent or dishonest acts or gross abuse of authority or discretion, and to bar his re-election, while $\$ 2236$ permits a summary action to determine the validity of a director's election. See also Remillard Brick Co. v. Remillard-Dandini Co, 109 Cal. App. 2d 405, 241 P.2d 66 (1952), where the directors of a corporation were removed for a breach of their fiduciary duty. 
Furthermore, if dissension should arise on the board, the use of an executive committee by the majority directors would mitigate its effects. ${ }^{61}$ Even though an executive committee might not eliminate the more conservative management attitude that could result from constant criticism, it would enable the corporation to retain a smoothly functioning administrative team of directors. Finally, there is evidence that successful proxy fights under cumulative voting, though more frequent, are more often aimed toward obtaining representation on, rather than control of, the board of directors; ${ }^{62}$ this may indicate that they tend to be less bitterly contested. These factors should be weighed against the possibility of ill effects from cumulative voting in determining whether incorporation outside California is desirable.

\section{B. Payment of Dividends}

Because California, Delaware, and Nevada all permit dividends to be paid from the net profits of the preceding accounting period or fiscal year ${ }^{63}$ as well as from surplus, ${ }^{64}$ and because all three states permit wasting asset corporations to pay dividends without setting aside a reserve for depletion, ${ }^{65}$ their domiciliary corporations normally should have little trouble finding a source for the payment of dividends. However, unlike Delaware and Nevada, which permit dividends to be paid to any class of shares from any available surplus account, California limits payment of dividends from paid-in or reduction surplus to preferred shares, if there are any such shares outstanding. ${ }^{68}$ In rare situations, this difference might prove significant. For instance, consider a California corporation with a capital structure including both common and preferred shares, which has become successful after a lean period that resulted in the mipairment of part of the stated capital attributable to the common shares. Since California permits payment from the earnings of the previous accounting period under such conditions, the corporation still could pay dividends to both common and preferred shares. However, if it were to fail to show a net profit for one accounting period, its directors would not be able to maintain a policy of paying regular dividends on the common shares. A Delaware or Nevada corporation, on the other hand, could pay dividends to conimon shares from paid-in or reduction surplus under such circumstances.

\section{Limits on Repurchase by the Corporation of its Own Shares}

Although all three states permit a corporation to repurchase its own shares, ${ }^{67}$ the California code imposes limits similar to those placed on the payment of dividends. A California corporation may repurchase any of its shares out of earned surplus. However, repurchase from reduction surplus is limited to preferred shares, if there are any such slares outstanding. Moreover, stated capital and paid-in

61 CAL. CORP. CODE $\$ 822$.

02 See Wriliams, op. cit. supra note 57, at 68-69, 164-66.

63 CAL. CORP. CODE $\$ 1500$ allows dividends to be paid from the net profits of the previous accounting period, which can be from six unonths to one year in length. DEL. CoDE ANN. tit. 8, $\$ 170$ (1953) and NEv. REv. STAT. $\$ 78.290$ (1957) both permit dividends to be paid from the profits of the current fiscal year and/or the preceding fiscal year.

64 Cat. Corp. Code § 1500; Dex. Code Ann. tit. 8, § 170 (1953); Nev. Rev. Stat. $\$ 78.290$ (1957).

o5 Car. Corp. Code \& 1503; Des. Code AnN. tit. 8, § 170(b) (1953); Nev. Rev. Stat. $\S 78.290$ (1957).

66 Cat. Corp. Code $\$ \S 1500,1906$.

67 Car. Corp. Code $\$ \S 801,1700,1704$; Det. Code ANN. tit. 8, $\$ 160$ (1953); Nev. Rev. STAT. \& 78.070 (1959). 
surplus can be used for repurchase only in special situations, e.g., to redeem preferred shares, or to compromise a debt. ${ }^{6 s}$ In contrast, Delaware and Nevada permit shares to be repurchased from any surplus. ${ }^{68}$

It may sometimes be useful, particularly in the case of a closely held corporation, to have the corporation purchase a shareholder's interest-perhaps to enable him or his family to meet an emergency or to buy out the interests of unhappy heirs. A corporation with both common and preferred shares outstanding and without a large earned surplus might find it difficult under California law to purchase from a common shareholder. Under Delaware or Nevada law, a paid-in or reduction surplus could be employed to purchase either common or preferred shares. To some extent, however, such eventualities may be provided for under California law through insurance, or through the use of debt securities or classes of common shares rather than preferred shares. ${ }^{70}$

\section{Quorum Requirements}

A California statute fixes a quorum at shareholders' meetings as "the presence in person or proxy of the persons entitled to vote a majority of the voting shares."71 Delaware leaves the question to the charter or by-laws, ${ }^{72}$ while the Nevada code is silent on the matter. It has been suggested that in some businesses it might occasionally prove difficult to obtain proxies from the holders of a majority of the voting shares. ${ }^{73}$ In light of the availability of professional proxy solicitors, however, quorum requirements should prove significant only in rare circumstances.

\section{E. Position of the Corporation's Management}

The promoters and potential managers of a corporation-those who in practice will ordinarily choose the state of incorporation-should bear in mind that their position is not as strong under the California General Corporation Law as it is under the Delaware and Nevada laws. The California cumulative voting provisions have been mentioned supra. It is easier for the shareholders to remove directors under the California law than under the laws of the two "liberal" states. "When certain rights of a class of shares would be adversely affected by a merger, consolidation, ${ }^{76}$ or amendment of the articles, ${ }^{76}$ California requires approval by a larger majority of such classes than do Delaware or Nevada. In addition, the civil and criminal liabilities of directors and officers of a corporation are greater under the

68 CAL. CORP. CODE $\$ \$ 1706,1707$.

68 Der. Code ANN. tit. 8, $\$ 160$ (1953) ; Nev. Rev. STAT. $\$ 78.070$ (1959).

70 For a general discussion of the problems of payment of dividends and of the purchase and redemption of shares, see Millikan, Corporate Purchase of Own Shares, Continuing Education of Bar, Aovising Caldrornia Business Enterprises 881 (1958); Ballantine \& Hills, Corporate Capital and Restrictions Upon Dividends Under Modern Corporation Laws, 23 CalIE. L. REv. 229 (1935).

71 Cax. Corp. CODE $\S 2211$.

72 Dex. CODE ANN. tit. 8, \$216 (1953).

73 See Garrett, Where to Incorporate, 37 Iru. B.J. SuppLENENr 386, 391 (1949).

74 Compare Cat. CoRP. Code $\$ \S 810,811$; Nev. Rev. Stat. $\$ 78.335$ (1957); Campbell v. Loew's, Inc., 134 A.2d 852 (Del. Ch. 1957). See also the Appendix at notes 144-47 infra.

75 Compare Cax. Corp. Code $\$ \S 4107,4112,4124$; Des. Code ANN. tit. 8 , $\S \S 251$ (c), 253 (1953) ; NEv. REv. Stat. $\$ \$ 78.470,78.485,78.540$ (1957). See also the Appendix at notes 235-40 infra.

76 Compare Cax. CoRp. Code $\S \S 3602,3632,3634,3635$; Dex. Code ANn. tit. 8, $\$ \S 242$ (a) (5), 242 (d) (1) (1953); Nev. REv. Stat. $\$ 78.385$ (1957). See also the Appendix at notes 232-34 infra. 
California law than uuder the laws of the other two states. ${ }^{77}$ Though these provisions probably would have no effect on a corporation's business, in practice they may well enter into the choice of a state of incorporation.

IV

\section{CORPORATE SECURITIES LAW}

Probably the inost striking difference between the California law and the laws of Delaware and Nevada lies in the administrative regulation of corporations. While the California Corporate Securities Law embodies one of the most comprehensive regulatory schemes in the country, ${ }^{78}$ neither Delaware nor Nevada has a "blue sky" law. ${ }^{79}$ Under the present California law, a permit from the Commissioner of Corporations is required for the issuance of securities by California corporations ${ }^{80}$ and by foreign corporations to the extent that they sell securities in this state. ${ }^{81}$ The Commissioner must also approve mergers, consolidations, and charter or by-law amendments affecting the rights of the holders of outstanding shares, whether undertaken by California corporations or by foreign corporations with California shareholders. ${ }^{82}$

Because the California regulations normally apply with equal force to Cahifornia corporations and to foreign corporations selling securities in the state, a business usually cannot avoid regulation in California simply by incorporating elsewhere. Therefore, the provisions of the California "blue sky" law, whether or not desirable from a management viewpoint, will bear upon the choice of a domicile for a business that plans to sell securities to California residents only in those special situations in which the California law does not apply to foreign corporations. At this point an exammation will be made of these special situations, as well as of some of the California administrative regulations that may make foreign incorporation desirable when such situations arise.

\section{A. Issuance of Securities in California}

The present Cahifornia Corporate Securities Law authorizes the Commissioner of Corporations to refuse to issue a permit to sell securities if he feels it would not be "fair, just, and equitable" to grant it. ${ }^{83}$ Under the regulations prescribed to implement this power, ${ }^{84}$ the Commissioner must approve both the price ${ }^{85}$ and the contractual provisions ${ }^{86}$ of the securities to be issued. Several of these regulations restrict corporate practices permitted elsewhere. For example, they provide that the sale of nonvoting or limited voting common shares will generally be "viewed with disfavor" when determining whether a pernit should be granted. ${ }^{87}$ The same view will be taken of the financing of a business not having a "satisfactory,

77 Compare Car. Corp. CoDe $\$ \S 824,825,1511,3015-22$; Dex. Code ANn. tit. $8, \S \S 144,174$ (1953); NEv. Rev. Stat. $\$ 78.145,78.300$ (1957). See also the Appendix at notes 158-68 infra.

78 See Loss \& CowetT, BLue Sky Law at 35-36, 73-75 (1958).

79 Id. at 17 .

80 CAT. CORP. CODE $\$ \$ 25500,25507,25009$ (a).

81 Ibid. See the discussion in note 35 supra.

82 CaL. CORP. CODE $\$ 25510$; tit. 10 CAL. ADM. CODE $\$ 759$.

83 CAT. CORP. CODE $\$ \S 25507,25510$.

84 Tit. 10 CaL. ADM. CODE $\$ \$ 300-860$.

85 Tit. 10 Cax. AdM. Code $\$ \S 337-39$.

${ }^{86}$ See generally Tit. 10 CaI. AdM. Code $\$ \$ 300-860$.

87 Tit. 10 CAL. ADM. CODE $\$ 367.1$. 
seasoned, earning record" with shares that are noncumulative, nonparticipating, or redeemable (unless convertible on an equitable basis). ${ }^{88}$

When a permit is sought to issue promotional shares, i.e., those issued for intangible assets whose value cannot be established to the Commissioner's satisfaction, further restrictions may be imposed. The promotional shares must be placed in escrow..$^{80}$ As long as the Commissioner requires the shares to be kept in escrow, ${ }^{00}$ the promoters must waive all rights both to receive dividends until after the nonpromotional shares have received cumulative dividends of at least $5 \%$ per annum, and to participate in liquidation until after the non-promotional shares have received the return of the consideration originally paid. ${ }^{21}$ Furthermore, the holders of non-promotional shares must be given the right to elect a majority of the board of directors if there has been a two-year default in payment of their $5 \%$ cumulative dividends. ${ }^{92}$

It should be kept in mind that most of the Commissioner's regulations may be waived in special cases. ${ }^{03}$ In particular, most can be avoided by an escrow of all the shares to be issued. ${ }^{94}$ However, such an escrow makes a wide distribution of the shares virtually impossible. Moreover, since an escrow emphasizes to the prospective buyer the aspects of the transaction that the Commissioner finds undesirable, it is likely to reduce the resale value of the securities.

\section{$B$. Effect of Foreign Incorporation}

Since the California Corporate Securities Law applies to foreign corporations that wish to sell securities in this state, ${ }^{95}$ it is usually pointless to attempt to avoid the Califorma blue sky provisions by foreign incorporation. In a few situations, however, foreign corporations may not have to comply with the provisions of the Califorma Corporate Securities Law. One such situation may arise when a foreign corporation plans to market its securities through foreign underwriters under such conditions that the underwriters would be considered the owners of the securities rather than the agents of the issuer, i.e., a "firm commitment" as opposed to a "best efforts" agreement. ${ }^{96}$ Since the sale by the issuer takes place outside Califorma, and since the underwriters are not selling a security of their own issue in this state, no permit is required. However, since California brokers must stop selling a security upon notice from the Commissioner that he considers the sale unfair, unjust, or inequitable, ${ }^{97}$ the underwriters will probably insist on substantial com-

88 Tit. 10 CaL. ADM. Code $\$ 364$.

89 Tit. 10 CaI. ADM. Code $\$ 370$.

90 Shares will be kept in escrow until the reason for putting them there no longer exists. See Tit. 10 CaL. AdMr. Code $\$ \$ 417-19$; Wheat, Issuance of Securities Under the California Corporate Securities Law, Continuing Education of Bar, Advising Calmornia Business EnterPRISES 541-42 (1958).

01 Tit. 10 Car. ADM. CODE § 372.

92 Tit. 10 CAL. ADM. CODE \& 373; Wheat, op. cit. supra note 90, at 544.

03 For example, many regulations state that a given practice will be "viewed with disfavor," not that it is forbidden. See, e.g., Tit. 10 CAL. ADM. CODE \$ 367.1.

94 See Wheat, op. cit. supra note 90, at 532-33, 545 .

95 CaL. Corp. Code § 25500; Gillis v. Pan. Am. W. Petroleum Co., 3 Cal. 2d 249, 44 P.2d 311 (1935).

${ }^{86}$ See Dahlquist, Regulation and Civil Liability Under the California Corporate Securities Act: II, 34 CarTF. L. Rev. 344, 381-83 (1946).

97 CaL. Corp. Code $\$ 25712$; Tit. 10 CaL. AdM. Code $\$ 681$. In practice, the Commissioner's office notifies the underwriters or brokers informally that the foreign security is unacceptable, whereupon the latter withdraw the offer from California. 
pliance with the California regulations if they plan to sell the security in this state. Some deviation from the California pattern may be tolerated by the Commissioner, however, in issues by well-established foreign corporations.

Even if a California enterprise does not plan to deal with foreign underwriters on a "firm commitnent" basis, it might wish to seek a foreign domicile to retain the option of complying with the California permit requirements or of trying to raise its capital elsewhere. Under the present California law, a domestic corporation has no such cloice; it must secure a permit for all securities issued, whether sold in California or elsewhere.98

A second situation in which a foreign corporation might not be subject to the California securities regulations arises when a company sells its securities to California residents in a transaction entirely negotiated and completed outside of California. If there have been no negotiations, offers, sales, or deliveries of securities in California, the California law does not apply. ${ }^{99}$ However, it would be a rare case in which a sale could be made to a California resident without any preliminary offers or negotiations taking place within this state. ${ }^{100}$ Thus, the possibility of financing a corporation througl out-of-state transactions with California residents does not seem to be worth the risks involved. If an over-zealous client were to make an offer or to conduct negotiations in California-or if such acts were alleged by disgruntled purchasers - both the individual involved and the corporation might be subject to severe criminal penalties. ${ }^{101}$ And if the securities were delivered in California, the Califorma conflicts of laws rule would result in the application of California law to the transaction, making the securities voidable for want of a permit. ${ }^{102}$

Additional problems might be raised by the resale in California of securities issued in a completely foreign transaction. It is clear that the permit exemption that applies to a bona fide owner selling for his own account ${ }^{103}$ is not available to an agent for a foreign corporation who purchases for re-sale in Califorma. ${ }^{104}$ This exemption is also unavailable when the sale is directly or indirectly in proinotion of a scheme for evading the California Corporate Securities Law. ${ }^{105} \mathrm{Be}$ cause of these two rules, it is possible that the purchaser of securities in a completely out-of-state transaction might still have to secure a permit should he ever wish to re-sell in California.

88 CAx. CORP. CODE $\$ \S 25500,25003$. See note 35 supra.

99 CAx. CORP. CODE $\$ \$ 25500,26100$. See LOSS \& Cowert, Brue Szy Law at 200-08; Dahlquist, op. cit. supra note 96, at 380-94; Note, Confitct of Laws: Liability for Interstate Sales of Securities Under State Blue Sky Lazes, 31 CALIF. L. REv. 95 (1942); Christopher, Conflict of Laws: Corporate Securities Act: Necessity of Permit, 11 So. CaLIF. L. Rev. 345 (1938).

100 Although at least one case, B.C. Turf \& Country Club v. Daugherty, 94 Cal. App. 2d 320,210 P.2d 760 (1949), permitted "preliminary negotiations" in California without a permit, it dealt with a case where no attempt was made to avoid the California law, and it was based partly on the premise that a regular permit could not be issued merely to talk to people about the possibility of organizing a busimess. However, the Corporations Code now specifically provides for negotiating permits, which are unavailable uuless an ordinary permit will eventually be sought. CAL. CoRP. CODE \$\$25516-17. Therefore, the B.C. Turf and Country Chub case should not be relied upon for the proposition that "preliminary negotiations" can be conducted in California without violating the Corporate Securities Law.

101 Cax. Corp. CODE $\$ \$ 26100-04$.

102 Robbins v. Pacific E. Corp., 8 Cal.2d 241, 65 P.2d 42 (1937); Dahlquist, op. cit. supra note 96 , at 385-97.

103 Cal. Corp. Code $\$ 25152$.

${ }^{104}$ Auslen v. Thompson, 38 Cal. App. 2d 204, 101 P.2d 136 (1940).

105 Cat. CoRp. Code $\$ 25152$. 


\section{Approval of Fundamental Corporate Changes}

Unlike most other states, California's Corporate Securities Law applies to fundamental changes in the corporate structure-mergers, consolidations, and charter or by-law amendments affecting the rights of outstanding shares. ${ }^{108}$ The Commissioner of Corporations may refuse a permit to a corporation seeking to make such changes if he feels that it would not be fair, just, or equitable to all security holders affected. ${ }^{107}$ Though some may object in principle to such broad admimistrative regulation, it is difficult to point to specific instances in which the Commissioner's regulations would impinge on legitimate business practices. ${ }^{108} \mathrm{On}$ the other hand, administrative approval of a merger or other change may prove helpful in protecting the corporation in case of a suit by a dissatisfied shareholder.

Since the full extent of the Commissioner's statutory authority over foreign corporations - as well as the constitutional limitations on its exercise-is not yet clear, it is difficult to determine whether a corporation with California shareholders but with only minimal Cahforuia contacts could avoid continuing regulation by the Commissioner of Corporations through incorporation in another state. The California statutes appear broad enough to allow the Commissioner to assert jurisdiction over fundamental changes in foreigu corporations if one shareholder resides in the state, ${ }^{109}$ particularly if the shares were sold to him in California. ${ }^{110}$ However, since the cases upholding the commissioner's jurisdiction over foreign corporations deal with enterprises having numerous California contacts, ${ }^{111}$ the question of whether the courts would permit such a broad exercise of jurisdiction remains unsettled.

\section{Effect of the Proposed Uniform Securities Act}

During the past two regular sessions, an amended version of the Uniform Securities Act has been introduced in the California legislature. ${ }^{112}$ The Act has raised a number of hotly debated questions concerning the proper scope of securities regulation, which are beyond the scope of this cominent. ${ }^{113}$ However, a side-effect of the Act would be to reduce the number of situations in which a foreign cor-

106 Car. Corp. Code $\$ \S 25500,25510,25009$ (a) ; Tit. 10 Car. AdM. Code $\$ \S 759-84$. Provisions of the General Corporation Law affecting fundamental changes in the corporate structure are discussed im the text at note 77 supra and in the Appendix infra.

107 Car. CORP. CODE $\$ 25510$.

108 Cf. Orschel, Administrative Protection for Shareholders in California Recapitalizations, 4 STAN. L. REV. 215 (1952).

${ }^{109}$ See Car. CoRP. Code $\$ \S 25500,25510,25009$ (a) ; Dahlquist, op. cit. supra note 96, at 380 .

$110 \mathrm{It}$ could be argued that continuing control by the Commissioner of Corporations over corporations that have secured a California permit to sell securities is necessary in order to insure that the permit requirements are not disregarded after the permit has been issued.

111 In the recent case of Western Air Lines, Inc. v. Sobieski, 191 A.C.A. 393, 12 Cal. Rptr. 719 (1961), the court found that the Coumissioner of Corporations had jurisdiction to pass on an amendment of the articles of a Delaware corporation designed to eliminate its cumulative voting provisions. In that case, however, the business had originally been incorporated in California, but had transferred its corporate domicile to Delaware through an exchange of the securities of the California corporation for those of a Delaware corporation. In addition, the holders of over $30 \%$ of the corporation's shares were California residents, and a large proportion of the corporation's busmess was done in California. (1961).

112 A.B. 2531, Cal. Leg., Reg. (Gen.) Sess. (1959) ; A.B. 1551, Cal. Leg., Reg. (Gen.) Sess.

${ }^{113}$ See, e.g., Jennings, The Role of the States in Corporate Regulation and Investor Protection, 23 LAw \& ConTEMP. Prob. 213-29 (1958); Edwards, California Measures the Uniform Securities Act against Its Corporate Securities Law, 15 Bus. Law. 814 (1960). 
poration would have an advantage over a corporation formed in California, through a reduction in the coverage of the present Corporate Securities Law.

At least two of the exemptions available under the amended Uniform Act might have a significant effect upon the choice of a corporate domicile. One such exemption would apply to transactions between an issuer and an underwriter, regardless of the domicile of either.114 Because of this exemption, a corporation employing "firm commitment" underwriting would be given the same treatment in California no matter where it was incorporated. ${ }^{115} \mathrm{~A}$ second exemption would apply when, after the projected sale, the stock would be owned by ten or fewer persons. Although a simplified notice would have to be filed with the commissioner upon the sale or re-sale of such shares, a permit fee would not have to be paid.116 This exemption would cover most of the situations in which financing through a transaction negotiated and completed out-of-state might be attempted. ${ }^{117}$

There is also a significant difference in scope between the amended Uniform Act and the present law. The forner applies to the "sale" of securities in California, ${ }^{118}$ rather than to the sale by a company of a security of its own "issue."119 Consequently, under the amended Uniform Act a California corporation would not have to secure a permit and pay a permit fee in order to sell its securities in a foreign state. It would also have the option now enjoyed by foreign corporations to forego sale of its securities in California rather than to conform with the Coinmissioner's regulations.

\section{E. California as a. Corporate "Home Away from Home"}

Under the present Cahiforma Corporate Securities Law, Califorma is effectively eliminated from the hist of possible domiciles for corporations which foresee no other contact with the state, since its permit requirenents and fees would apply to a Califorma corporation that sold no securities in Califorma. ${ }^{120}$ Under the amended Uniform Act, however, the "blue sky" law would apply only if securities were sold in the state ${ }^{121}$ or if its principal business or place of business were located here. ${ }^{122}$ Therefore, under the amended Uniform Act there would appear to be no substantial drawbacks to incorporating an entirely foreign enterprise in California, if the approach of the California General Corporation Law happened to suit the organizers' taste.

\section{V}

\section{ADDITIONAL FACTORS}

In a situation where the business being incorporated is hkely to grow rapidly, and where the attorney would prefer to incorporate a larger business under the laws of another state, the ease with which the corporate domicile can be changed becomes a factor to be considered. Such a change is usually effected by merging

114 A.B. 1551, Cal. Leg., Reg. (Gen.) Sess. \$25402(b) (4) (1961); UNIFORM SecurITIES ACT $\$ 402(b)$ (4).

115 See text at note 96 supra.

116 A.B. 1551, Cal. Leg., Reg. (Gen.) Sess. § 25403(b) (12) (1961).

117 See text at note 99 supra.

118 A.B. 1551, Cal. Leg., Reg. (Gen.) Sess. § 25301 (1961) ; UnIForar SecurItIEs ACT § 301.

118 CAL. CoRP. Code $\$ \S 25500,26100$.

120 See CAL. CORP. CODE $\S \S 25003,25500,26003$.

121 A.B. 1551, Cal. Leg., Reg. (Gen.) Sess. § 25301 (1961) ; UnIForar SecurmIrs Act § 301.

122 A.B. 1551, Cal. Leg., Reg. (Gen.) Sess. \$ 25401 (j) (1961). 
or consolidating with a foreign corporation, or by selling all the assets of the domestic corporation to a foreign corporation in return for sliares of the latter. Under both the present California $\mathrm{law}^{123}$ and the amended Uniform Securities Act, ${ }^{124}$ the Commissioner of Corporations could prevent such a move if he felt it was unfair to some of the security holders involved. For this reason, it might prove unwise to incorporate in California with the intent of subsequently moving the corporate domicile to another state.

Another obvious but important factor in choosing a corporate domicile is the -attorney's relative knowledge of the laws of the states in question. It may often be better to incorporate in the attorney's state in order to avoid the pitfalls of an unfamiliar foreign law.

\section{VI}

\section{CONCLUSTON}

Incorporation under the laws of Delaware or Nevada rather than under the law of Cahfornia may be advantageous in a few instances. Under the present California Corporate Securities Law, a completely foreign enterprise would submit itself needlessly to California securities regulation by incorporating in this state. And a corporation planning to engage in "firm commitment" underwritimg with foreigu underwriters or planning to sell its securities in a number of states will find it somewhat less expensive to incorporate in Delaware or Nevada, and may be subject to fewer administrative restrictions as well. On the other hand, the cost of a corporation service company and the $\$ 350$ California entrance fee makes California incorporation less expensive for small business enterprises doing business solely in California. In addition, a California attorney may prefer California incorporation if he has a better knowledge of California law than of the laws of Delaware or Nevada.

In most cases, however, there are no business advantages to be gained from a choice among the three states studied. Since discriminatory taxation in the three states involves relatively small amounts, tax savings are usually of little importance. The General Corporation Laws of all three states provide modern enabling acts, and the California provisions designed to protect security holders' interests would not affect the operation of a corporation's business or the position of a corporation's management with sufficient frequency to be significant factors. Because of the broad applicability of the Cahfornia Corporate Securities Law, foreign incorporation alone ordinarily will not enable a business to avoid the law's effects if it wishes to sell securities in California. However, the availability of corporation service companies inakes incorporation in a distant state a simple matter, should that prove desirable. Because of these factors, it normally should make hittle difference to those organizing or managing a business with California contacts whether California, Delaware, or Nevada is selected as the state of incorporation.

\section{Francis G. Willmarth*}

123 Cax. Corp. Code $\S 25510$; Tit. 10 Cax. Adm. Code $\S 759$.

124 A.B. 1551, Cal. Leg., Reg. (Gen.) Sess. § 25401 (j) (1961).

* Member, Class of 1961. 


\section{APPENDIX-COMPARISON OF GENERAL CORPORATION STATUTES}

\section{A. GENERAL POWERS OF THE CORPORATION}

1. Califorma, Delaware, and Nevada all permit a corporation to be formed for any lawful purpose, 125 and to exist for an unlimited time. ${ }^{126}$

2. All three states have similar grants of general corporate powers, e.g., to sue and be sued, to appoint officers and agents, to hold real estate, to make charitable donations.127 In addition, Delaware and Nevada permit the exercise of powers needed to carry out the objects set forth in the certificate of incorporation. These powers must be expressly set forth in the charter under Delaware law; 128 under Nevada law they are implied powers. ${ }^{129}$ California cases liave held that a corporation has powers imphed from those specifically granted in its charter. ${ }^{130}$

\section{B. DIRECTORS}

1. All three states require no less than three directors. ${ }^{131}$

2. California has no citizenship or residence requirements for incorporators or directors. ${ }^{132}$ The Nevada code requires all directors to be of full age and at least one to be a United States citizen, but otherwise is silent. ${ }^{133}$ The Delaware code is silent both as to incorporators and directors. ${ }^{134}$

3. None of the three requires directors to be shareholders, unless the articles or by-laws so require. ${ }^{135}$

4. All three states permit meetings of the board of directors to be held either within or outside of the state of incorporation, subject to the corporation's by-laws. 136

5. All three permit the validation of an improperly called directors' meeting if a quorum was present and if each director not present signed a written waiver of notice before or after the meeting. ${ }^{137}$ In addition, Delaware and Nevada expressly permit director action to be taken without a meeting if prior consent is given by all the directors, unless the articles or by-laws otherwise provide. 138

6. All three states make provisions for executive committees. ${ }^{139}$

7. California makes cunulative voting mandatory; Delaware and Nevada make it permissive only. 140

8. California forbids staggering of the terms of the directors; Delaware and Nevada permit it within limits. ${ }^{141}$

125 CaI. Corp. Code § 300; Dex. Code ANN. tit. 8, § 101 (1953); Nev. Rev. Stat. $\$ 78.030$ (1957).

126 Cat. Corp. Code § 308; Dex. Code Ann. tit. 8, §102(6) (1953); Nev. Rev. Stat. $\$ 78.035(8)$ (1957).

127 CaL. Corp. Code \$§ 801-02; Dez. Code ANN. tit. 8, \$§ 121-23 (1953) ; Nev. Rev. Stat. $\S \S 78.060-70$ (1959).

128 DEL. CODE ANN. tit. 8, \& 121 (1953).

$12 \theta$ Nev. Rev. StaT. $\$ 78.070(5)$ (1959).

130 Vandall v. South San Francisco Dock Co., 40 Cal. 83 (1870) ; Bailey v. Guaranty Liquidating Corp., 16 Cal. App. 2d 401, 60 P.2d 579 (1936).

131 CaL. Corp. Code § 800; Dex. Code ANN. tit. 8, §141(b) (1953); Nev. Rev. Stat.

$\S 78.115$ (1957).

132 CAL. CORP. CODE $\$ \S 307,804$.

133 See NEV. REv. StaT. $\$ \S 78.030,78.115$ (1957).

134 See DeL. CODE ANw. tit. 8, \$§ 101, 141 (1953).

135 CaI. Corp. Code \$ 804; Dex. Code ANN. tit. 8, §141(b) (1953); Nev. Rev. Stat. $\$ 78.115$ (1957).

136 Cat. Corp. Code § 815; Dex. Code ANv. tit. 8, § 211 (1953) ; Nev. Rev. Stat. \$ 78.310 (1957).

137 Cat. Corp. Code § 814; Dez. Code ANw. tit. 8, § 229 (1953); Nev. Rev. Stat. § 78.325, 78.375 (1957).

138 Ded. Code ANn. tit. 8, § 141 (g) (1957) ; Nev. Rev. Stat. § 78.315 (1959).

130 Cal. Corp. Code \$ 822; Dex. Code AnN. tit. 8, \$141(c) (1953); Nev. Rev. Stat.

$\S 78.125$ (1957).

140 See notes 52-53 supra.

141 See notes 54-55 supra. 
9. All three states permit the directors to fill vacancies on the board unless the by-laws otherwise provide. 142

10. California permits the court to appoint a provisional director to the board upon petition by one-half of the directors or by the holders of one-third of the outstanding shares, if the board is equally divided and cannot agree as to the management of the corporation's affairs, and if the business can no longer be conducted to advantage or if property and business are in danger of being impaired and lost. ${ }^{143}$ Delaware and Nevada have no such provision.

11. California permits the removal of the entire broad of directors without cause by a majority of the voting shares; it allows the removal of an individual director without cause by a vote large enough to have prevented his election under cumulative voting. 144 In addition, the holders of ten per-cent of the outstanding shares may petition the court to remove a director for cause. ${ }^{145}$ Nevada permits removal of directors without cause by the holders of two-thirds of the voting shares, or, in corporations employing cumulative voting, by that number necessary to prevent the election of the directors. ${ }^{146}$ Delaware common law permits the holders of a majority of the voting shares to remove a director for cause. 147

12. California forbids a corporation to make loans to or guarantee the obligations of its directors or the directors of a parent or subsidiary corporation.148 Delaware merely forbids a corporation to make loans to its directors; ${ }^{149}$ Nevada las no code provision on the subject.

13. California and Nevada have similar statutes providing that interested director contracts or transactions are not invalidated merely because an interested director was present and voted at the meeting authorizing them, if there was a ratification in good faith and with knowledge of the conflict of interest by a majority of the disinterested directors or by a majority of the shareholders, or if the transaction was just and reasonable to the corporation at the time approved. 150 The statutes also provide that the interested director may be counted in determining whether a quorum was present at the directors meeting. In addition, the Nevada statute provides that the shares of the interested director may be counted in a shareliolder ratification of the transaction. However, the California cases have lield that a breach of the directors' statutory duty to exercise their powers in good faith could not be ratified by the board or by an interested majority of shareholders. 151

The Delaware code is silent on the problem of interested directors, and the Delaware common law is not completely clear. However, it appears that unless an interested director contract or transaction is completely void, e.g., ultra vires, illegal, or fraudulent, ${ }^{152}$ it may be validated if approved by a majority of disinterested directors having knowledge of the facts, 153 a disinterested quorum being present, 154 or by a majority of shareholders with knowledge of the facts.155 Once so approved, an objector has the burden of proving that no person of "sound business judgment would feel that the exchange was a fair one."15B Moreover, the Delaware court has upheld exculpatory charter provisions permitting an interested director to be counted toward a quorum. ${ }^{157}$

142 Cat. Corp. Code § 808; Dex. Code Ann. tit. 8, §142(e) (1953) ; Nev. Rev. Stat. $\S 78.335$ (2) (1957).

143 CaL. CORr. CODE $\$ 819$.

144 Cal. Corp. Code $\$ 810$.

145 CAL. CORP. CODE $\$ 811$.

146 Nev. Rev. STAT. § 78.335 (1957).

147 Campbell v. Loew's Inc., 134 A.2d 852 (Del. Cl. 1957).

148 CAL. CORP. CODE $\S 823$.

149 DEL. CODE ANN. tit. 8, § 143 (1953).

150 Cat. Corp. Code $\$ 820$; Nev. Rev. Stat. \$ 78.140 (1959).

151 Remillard Brick Co. v. Remillard-Dandim Co., 109 Cal. App. 2d 405, 241 P.2d 66

(1952). Cf. Kennerson v. Burbank Amusement Co., 120 Cal. App. 2d 157, 260 P.2d 823 (1953).

152 Keenan v. Eshleman, 23 Del. Ch. 234, 2 A.2d 904 (Sup. Ct. 1938). See also Gropper v.

North Cent. Texas Oil Co., 35 Del. Cli. 198, 114 A.2d 231 (Sup. Ct. 1955).

153 Loftland v. Cahall, 13 Del. Ch. 384, 118 Atl. 1 (Sup. Ct. 1922). But cf. Kerbs v. Cali-

fornia E. Airways, 32 Del. Ch. 219, 83 A.2d 473 (Ch. 1951), afj'd, 33 Del. Ch. 69, 90 A.2d 652

(Sup. Ct. 1952).

154 See Italo-Petroleum Corp. of America v. Hannigan, 1 Terry 534, 14 A.2d 401 (1940).

155 Kerbs v. California E. Airways, 33 Del. Ch. 69, 90 A.2d 652 (Sup. Ct. 1952).

156 Gottlieb v. Heyden Chemical Corp., 33 Del. Ch. 177, 91 A.2d 57 (Sup. Ct. 1952).

157 Sterling v. Mayflower Hotel Corp., 33 Del. Ch. 293, 93 A.2d 107 (Sup. Ct. 1952). 
14. All three states hold directors liable for the wrongful payment of dividends. 108 The California statute includes the wrongful distribution of a reduction surplus or of the corporation's assets, as well as the wrongful purchase of the corporation's shares; ${ }^{159}$ the Nevada statute includes distributions in fraud of creditors. 160

Under California law, directors making such wrongful disbursements are liable to the extent of the debts of the corporation existing at the time of payment plus the loss sustained by the holders of those shares that did not participate in the distribution. ${ }^{161}$ In addition, they may face criminal penalties for a willful violation. 162 Under Delaware law, directors are liable to the extent of the wrongful payments made, ${ }^{163}$ while under Nevada law they are liable up to the amount of the distribution or the loss suffered by the corporation, whichever is less.104

In all three states, reliance upon certain corporate records is a defense to any action; $\mathbf{1 0 5}$ a recorded dissent by a director also serves as a defense. 166

15. All three states make directors liable for the publication of false reports. 167 In addition, California and Delaware make them liable for loans wrongfully extended to directors or officers. 168

16. All three states permit a corporation to indemnify an officer or director for costs incurred in defending a suit to which he was made a party because of his corporate office. California permits indemnification for his expenses, judgments, or fines if the board of directors determines in good faith that he acted in good faith; Delaware and Nevada allow indemnification for his expenses unless he has been adjudged negligent or guilty of misconduct, plus any additional rehief provided through by-laws, agreements, shareholder votes, or otherwise. ${ }^{169}$ In addition, the California code provides that the corporation may be assessed by the court for the expenses of the officer or director if he is successful in whole or in part or if the proceedings are settled with approval of the court, and if the court finds that his conduct merits sueh indemnity. However, this latter provision applies to California suits involving eitler domestic or foreign corporations. 170

17. California and Delaware hoth limit derivative suits to transactions that occurred while the plaintiff was a registered shareholder. ${ }^{171}$ Nevada has no such provision. In addition, the California code provides for a motion by the corporation or an officer or director to require the plaintiff to furnish security, if there is no reasonable possibility of benefit to the corporation, or if the moving party did not participate in the transaction. ${ }^{172}$ Delaware and Nevada have no similar provisions. However, such a motion would probably he available to foreign domiciliaries when sued in California courts..$^{173}$

158 Cat. Corp. Code $\$ \S 824-25$; Dez. Code ANn. tit. 8, $\$ 174$ (1953); Nev. Rev. Stat. $\S 78.300$ (1957).

159 CAL. CORP. CODE $\$ \S 824,825,831,1907$.

180 NEv. REv. STAT. \$ 78.625 (1957).

161 CAL. CORP. CODE $\$ 825$. See also CAI. CORP. CODE $\$ 6601$, which makes the directors of foreign corporations liable in the courts of this state for such offenses as wrongful payment of dividends or distribution of assets, according to the law of the corporate domicile.

162 CAL. CORP. CODE $\$ 1511$.

163 Dex. CODE ANN. tit. 8, § 174 (1953).

104 NEV. REV. STAT. \$ 78.300 (1957).

105 CAL. CoRp. CODE $§ 829$; DEL. COdE ANN. tit. 8, $\$ 172$ (1953); Nev. Rev. Stat. $\$ 78.295$ (1957).

166 Cal. Corp. Code § 825; Det. Code ANn. tit. 8, § 174 (1953); Nev. Rev. Stat. § 78.300 (1957).

167 Cas. CoRp. Code $\S \S 3018-20 ;$ Dex. Code AnN. tit. 8, § 144 (1953); Nev. REv. Stat. $\S 78.145$ (1957). California imposes both civil and criminal penalties, while Delaware and Nevada impose civil liability only.

168 Car. Corp. CODE \& 823; Ded. COde ANn. tit. 8, § 143 (1953).

109 Cal. Corp. Code $\$ 830$; Dex. Code Ann. tit. 8, $\$ 122(10)$ (1953); Nev. Rev. Stat.

$\S 78.070(6)$ (1959).

170 CAL. CORP. CODE $\$ 830$.

171 CAI. CORP. CODE $\$ 834$.

172 Ibid.

173 Cf. Cohen v. Beneficial Loan Corp., 337 U.S. 541, 554 (1949) ; 1 Enrenzwerg, CoN-

FuCT OF LAWS $\$ 12$ (1959). 


\section{SHARES}

1. All three states provide for classes and series of shares, with or without par value, voting rights, preferences, or redemption or conversion rights. The directors may fix the rights and privileges of unissued classes of shares if the articles so provide.174

2. All three states provide for stock options. 175

3. Both California and Delaware permit the articles to give voting and inspection rights to bondholders. Delaware also authorizes the articles to grant bondholders any other rights shareholders may have;170 California authorizes a grant of any other rights shareholders may have to financial information about the corporation. ${ }^{177}$ Although Nevada authorizes the issu. ance of bonds, 178 its code is silent as to permissible bondholders' rights .

4. Delaware and Nevada give shareholders pre-emptive rights unless the articles provide otherwise; ${ }^{179}$ California recognizes pre-emptive rights only if the articles provide for them. ${ }^{180}$

5. California and Nevada allow assessment of shares only if the articles so provide. ${ }^{181}$ Though Delaware does not permit assessment of fully paid shares, it does permit shares to be issued partly paid and subject to call for the remainder. 182

6. All three states permit shares to be issued for money, for labor or services performed, or for property received. Absent fraud, the deternination of the directors as to the value of the consideration received is final. 183

7. All three states permit the directors to allocate part of the consideration for shares to surplus rather than to capital. Delaware and Nevada pernit the allocation of any consideration received from the sale of no-par shares, plus any consideration from the sale of par shares in excess of par value.184 California permits the allocation of the consideration from the sale of no-par common shares, plus any consideration from the sale of par shares in excess of par value, or in excess of a lower sale price if such a price was properly authorized.185 All three states also permit transfer from surplus to stated capital.186

8. All three states permit a corporation to re-purchase its own shares. 187 Delaware and Nevada limit this power to cases in which no impairment of capital would result except in certain instances where its capital is being reduced or its preferred shares are being redeemed.188 California limits it to cases in which there would he no impairment of that portion of its capital attributable to shares having preferences equal or prior to those of the shares being repurchased, and in which the corporation would still be able to meet its debts and liabilities as they fell due. ${ }^{189}$ In addition, California limits the sources that may be used to repurchase shares. Subject to the corporation's articles, earned surplus can be used to repurchase any kind of shares. 190 However, reduction surplus can be used only to repurchase preferred shares, if there are any such shares outstanding.191 Paid-in surplus and stated capital can be used for repurchase only in limited situations: To compromise a debt, to eliminate fractional shares, to redeem or purchase shares subject to redemption, to buy out a dissenting shareholder in a merger,

174 Cal. Corp. Code \$\$1100-03; Des. Code ANs. tit. 8, § 151 (1953); Nev. Rev. Code $\S 78.195$ (1957).

175 Cal. Corp. Code § 1104; Del. Code ANN. tit. 8, § 157 (1953); Nev. Rev. Stat. § 78.200 (1957).

176 Des. Code ANr. tit. 8, 8221 (1953).

177 CAL. CORP. CODE $\$ 306$.

178 NEv. REv. STAT. \& 78.070 (1957).

179 DeI. CODE ANn. tit. 8, § 102 (b) (3) (1953); NEv. REv. Stat. \& 78.265 (1957).

180 CAL. CORP. CODE $\$ 1106$.

181 Cat. Corp. Code $\$ \S 305,2700$; Nev. Rev. Stat. $\$ 78.275$ (1957).

182 DEs. CODE ANN. tit. 8, §§ 152, 156 (1953).

183 Cal. Corp. Code $\$ \S 1109-12$; Det. COde AnN. tit. 8, § 152 (1953); Nev. Rev. Stat. $\S 78.210$ (1957).

184 Dex. Code AnN. tit. 8, § 154 (1953) ; Nev. REv. Stat. § 78.270 (1957).

185 CaL. Corp. Code $\$ \S 1900,1901$.

(1957).

186 Cal. Corp. COde $\$ 1903$; Del. Code AnN. tit. 8, § 154 (1953); Nev. Rev. Stat. $\$ 78.270$

187 See note 67 sicpra.

188 Del. Code AnN. tit. 8, § 160 (1953); Nev. Rev. Stat. § 78.073(3) (1959).

189 CAL. Corp. Code $\$ 1708$.

190 Cat. Corp. Code $\$ 1707$.

191 Cat. Corp. CODE $\$ \S 1707,1906$. 
to buy from an employee under an option to repurchase, or to effect an exchange of shares pursuant to provisions of its articles authorizing conversion of shares. 192

\section{SHAREHOLDERS}

1. All three states permit shareholder meetings to be held either within or outside the state. ${ }^{103}$

2. California imposes a quorum requirement of the presence in person or proxy of the persons entitled to vote a majority of the voting shares.194 Delaware leaves the question to the articles or by-laws, ${ }^{195}$ while the Nevada code is silent on the question.

3. All three states permit a sharcholder to waive notice of a meeting, either before or after it is held.190 All three also permit shareholder action to be taken without a meeting if, prior to the proposed action, a specified number sign a written consent. 197 California and Delaware require consent by all concerned; $\mathbf{1 0 8}$ Nevada permits consent by a majority unless a larger vote is prescribed by the articles or by statute. ${ }^{109}$ California will not permit shareholder action without a meeting in cases concerning the approval of mergers or consolidations, ${ }^{200}$ while Nevada forbids such procedures for the election of directors. ${ }^{201}$

4. California, Delaware, and Nevada provide that proxies shall be invalid after periods of 11 months, 3 years, and 6 months, respectively. ${ }^{202}$ All three states permit the person executing the proxy to specify a longer time.203 California and Nevada allow maximum periods of validity of 7 years. ${ }^{204}$

5. All three states make shareholders liable for unpaid share subscriptions.205 Delaware and Nevada impose no further statutory shareholder liabilities, although Delaware requires the articles of a Delaware corporation to state whether the private property of the shareholders is to be subject to corporate debts. ${ }^{206}$ California imposes civil liability on shareholders who have knowingly received unauthorized dividends, ${ }^{207}$ or who have knowingly allowed the corporation to repurchase their shares in an improper manner. ${ }^{208}$

\section{E. DIVIDENDS}

1. When a corporation's assets have been reduced below the sum of its habilities plus the capital attributable to preferred shares having liquidation preferences, Delaware and Nevada forbid all dividend payments; ${ }^{299}$ California permits payment of dividends under these circumstances, but only to preferred shares.210 California forbids all dividend payments when the corporation's assets would thereupon be less than its habilities, or when it would be unable to meet its debts and habilities as they matured.211

2. Delaware and Nevada permit dividends to be paid from any surplus, ${ }^{212}$ California

192 CAL. CORP. CODE $\$ 1706$.

103 CaL. Corp. Code $\$ 2210$; Del. Code Ann. tit. 8, § 211 (1953) ; Nev. Rev. Stat. \$ 78.310 (1957).

104 Car. CORP. CODE $\$ 2211$.

195 DEI. CODE ANN. tit. 8, $\$ 216$ (1953).

196 Car. CoRp. Code $\$ 2209$; Del. Code Ann. tit. 8, § 229 (1953) ; Nev. Rev. Stat. $\S 78.370(6)(1957)$.

197 Cax. Corp. COde $§ 2239$; Dex. Code Ans. tit. 8, §228 (1953); Nev. Rev. Stat.

$\S 78.320$ (1959).

108 Cal. Corp. Code $\$ 2239$; Del. Code AnN. tit. 8, § 228 (1953).

109 NEv. Rev. Stat. $\$ 78.320$ (1959).

200 Cat. CORP. CODE $\$ 2239$.

201 NEv. REv. STAT. \$ 78.320 (1959).

202 Cax. Corp. COde $\$ 2226$; Dex. Code Ann. tit. 8, § 212 (1953); Nev. Rev. Stat.

$\S 78.355$ (1957).

203 Ibid.

204 CAT. CoRp. Code $§ 2226$; NEv. REv. Stat. $\$ 78.355$ (1957).

205 Caz. Corp. COde $\S \S 1300-06$; Dez. Code AnN. tit. 8, $\$ 161$ (1953) ; Nev. Rev. Stat.

$\$ 78.225$ (1957).

206 Dex. CODE ANN. tit. 8, § 102 (a) (7) (1953).

207 CAL. CORP. CODE $\$ 1510$.

208 CAT. CORP. CODE $\$ 1715$.

209 DEL. CODE ANN. tit. 8, § 170 (1953) ; NEv. Rev. STAT. $§ 78.290$ (1957).

210 CAI. CORP. CODE $\$ 1500$ (b).

211 CAL. CORP. CODE $\$ 1501$.

212 DeL. Code ANN. tit. 8, § 170 (1953) ; Nev. Rev. Stat. $\$ 78.290$ (1957). 
allows them to be paid from earned surplus without himit; however, if there are any preferred shares outstanding, dividends from paid-in or reduction surplus can be paid only to preferred shares.213

3. California permits dividends to be paid from the net profits of the previous accounting periods, which may be from six months to one year in length;214 Delaware and Nevada allow them to be paid from the net profits of the current fiscal year and/or the preceding fiscal year.210

4. All three states permit dividends to be paid in shares. ${ }^{210}$ California permits payment only from earned, paid-in, or reduction surplus.217 Delaware and Nevada accord share dividends no special treatment.

5. All three states permit wasting asset corporations to pay dividends without sctting up a reserve for depletion. 218

\section{F. CHANGES IN STRUCTURE}

1. California permits by-laws to be adopted, amended, or repealed by the holders of a majority of the voting shares, or by the directors subject to the shareholders' power, unless the articles or by-laws require a larger sliareholders' vote or limit the directors' power. ${ }^{210}$ Delaware places the power to alter the by-laws with the sharcholders, unless the articles confer it upon the directors, 220 while Nevada places it with the directors, subject to by-laws made by the shareliolders.221

2. All three states provide for the sale of all assets upon approval of a majority of the voting shares, unless the articles require a larger vote.222 In addition, California and Nevada permit the directors to mortgage all the assets without seeking shareholder approval, absent express provision to the contrary in the articles.223 Though the Delaware courts have never considered the question, a federal court has stated that a mortgage of substantially all the property of a Delaware corporation must be approved by the shareholders.224

3. All three states provide for the reduction of stated capital by a number of means, e.g., reduction of par value, exehange of shares, and repurchase or redemption of shares.225 California and Nevada require a resolution by the board of directors plus approval of the holders of a majority of the sliares outstanding, whether voting shares or not, 220 while Delaware requires either approval by the holders of all voting shares or a board resolution plus approval of the holders of a majority of the voting shares.227

California and Nevada will not permit stated capital to be reduced below the aggregate par value of any common shares, plus the aggregate liquidation value of any preferred shares, remaining outstanding after the reduction. ${ }^{228}$ Delaware has no such limits.

California and Nevada will not permit the distribution of a reduction surplus when as a consequence the corporation would not be able to meet its debts and habilities as they mature. 229 Delaware has no similar provision in its code. In addition, California requires the assets remaining after distribution to equal one and a quarter times the debts and liabilities;230

213 CAL. CORP. CODE $\$ 1500$.

214 Ibid.

216 DeI. Code ANN. tit. 8, § 170 (1953); Nev. Rev. Stat. $\$ 78.290$ (1957).

216 Cat. Corp. Code $\$ 1504$; Des. Code AnN. tit. 8, $\$ 173$ (1953); Nev. Rev. Stat. $\S 78.290$ (1957).

217 CaL. Corp. CODE $\$ 1504$.

218 Cal. Corr. Code § 1503; Del. Code Ann. tit. 8, § 170(b) (1953); Nev. Rev. Stat.

$\S 78.290$ (1957).

219 CAL. CORP. CODE $\S 500$.

220 DEL. CODE ANN. tit. 8, § 109 (1953).

221 NEv. REv. Stat. \$ 78.120(2) (1957).

222 Cat. Corp. Code § 3901 ; Det. Code ANN. tit. 8, §271 (1953); Nev. Rev. Stat.

$\S 78.565$ (1957).

223 CaL. Corp. Code $\$ 3901$; Nev. Rev. Stat. $\$ 78.565$ (1957).

224 Greene v. RFC, 24 F. Supp. 181 (D. Mass. 1938), aff'd, 100 F.2d 34 (1st Cir. 1938).

225 Cat. Corp. Code § 1904; Dex. Code Anv. tit. 8, § 244 (1953) ; Nev. Rev. Stat.

$\$ \S 78.410-78.425$ (1957).

228 Cat. CoRp. Code $\S 1904$; Nev. Rev. Stat. $\$ \S 78.415-78.425$ (1957).

227 Det. CODE ANN. tit. 8, \& 244 (1953).

228 Cat. Corp. Code § 1904; Nev. Rev. Stat. § 78.430 (1957).

229 Cat. Corp. Code $\$ 1907$; Nev. Rev. Stat. \$ 78.440 (1957).

230 CAL. CORP. CODE $\$ 1907$. 
Delaware and Nevada require the assets remaining to equal the debts and liabilities not otherwise provided for. 231

4. All three states permit any lawful charter amendment.232 California requires approval by the holders of a majority of the voting shares. In addition, it requires approval by the holders of two-thirds of any class of voting or non-voting shares adversely affected by certain changes in the rights of that class. If any class is to be benefitted by such changes, it requires approval by the holders of a majority of the other voting and non-voting shares.233 Delaware and Nevada only require approval by the holders of a majority of the voting shares, plus the holders of a majority of any class of voting or non-voting shares adversely affected by certain changes in the rights of that class. ${ }^{234}$

5. All three states authorize corporate mergers. ${ }^{235}$ In addition to a resolution by the board of directors, California requires a merger to be approved by the holders of two-thirds of each class of shares; ${ }^{238}$ Delaware by the holders of two-thirds of the total shares; 237 Nevada by the holders of a majority of each class of slares. ${ }^{238}$ Though all three states provide a simple merger procedure for subsidiary corporations, which does not require a shareholder vote, Delaware permits it to be used in the case of a 90 per-cent owned subsidiary, while the other states limit its use to wholly owned subsidiaries.230 Unlike the other two states, the California code permits a corporation to abandon a merger without shareholder approval. 240

6. California permits the holders of 50 per-cent or more of the voting shares to dissolve the corporation at any time. It permits the directors to do so in certain limited situations, e.g., when the corporation is adjudged bankrupt.241 Delaware permits the corporation to be wound up by the holders of all the voting shares, while the holders of nine-tenths are required in Nevada. Both Delaware and Nevada permit dissolution when approved by a majority of the board and the liolders of two-thirds of the voting shares.242

7. The California Code permits an action for involuntary dissolution to be brought by 50 per-cent of the directors or by shareholders of record for 6 inonths who hold 331/3 per-cent of the outstanding shares. 243 This action can be brought for a number of abuses, e.g., an equally divided board of directors which cannot agree as to the management of affairs, and which is not conducting business to advantage or which is endangering the corporate property; two or more factions of shareholders which are so deadlocked that business cannot be conducted to advantage; persistent fraud, mismanagement, or abuse of authority, or persistent unfairness toward minority shareholders, or misapplication or waste of corporate property by those in control of the corporation. ${ }^{244}$ However, the holders of 50 per-cent of the outstanding shares may avoid the appointinent of a receiver by purchasing the shares of the plaintiffs at their fair cash value, ${ }^{245}$ which will be established by the court if the parties cannot agree.246

Nevada permits a similar action to be brought by the holders of one-tenth of the capital stock outstanding. 247 It may be brought for similar abuses, e.g., when the corporation lias wilfully violated its charter; when the directors bave been guilty of fraud, collusion, or gross mismanagement; or when the corporation cannot conduct business or conserve assets by reason of the act, neglect, or refusal to function of any of the directors. The Delaware Code provides for no such action.

231 Dex. Code ANn. tit. 8, \$ 244 (1953); Nev. Rev. Stat. \$ 78.440 (1957).

232 Cat. Corr. Code $\$ 3602$; Dex. Code AnN. tit. 8, \$242 (1953); Nev. Rev. Stat.

$\S 78.385$ (1957).

233 CAL. CORP. CODE $\$ \$ 3602,3632,3634-35$.

234 Dex. Code ANn. tit. 8, §§ 242 (a) (5), 242(d)(1) (1953); Nev. Rev. Stat. § 78.385

(1957).

235 Car. Corp. Code § 4103; Dex. Code Ann. tit. 8, § 251 (1953); Nev. Rev. Stat.

§ 78.455-85 (1957).

236 CAI. CORP. CODE $\$ 4107$.

237 DEL. CoDe ANN. tit. 8, § 251(c) (1953).

238 NEv. REv. STAT. $\$ \S 78.470,78.485$ (1957):

230 Car. Corp. Code $\$ 4124$; Del. Code Ann. tit. 8, $\$ 253$ (1953); Nev. Rev. Stat.

$\S 78.540$ (1957).

240 CAT. CORP. CODE $\$ 4112$.

241 CAT. CORP. CODE $\$ \$ 4600-01$.

242 Dex. Code ANN. tit. 8, § 275 (1953); NEv. Rev. Star. \& 78.580 (1957).

243 CAL. CORP. CODE $\$ 4650$.

244 CAL. CORP. CODE $\$ 4651$.

245 CAI. CORP. CODE $\$ 4658$.

246 CAT. CORP. CODE $\$ 4659$.

347 Nev. Rev. Stat. $\$ 78.650$ (1957). 